\title{
Social Capital as a Resource of Subjective Well-Being: Mediating Role of Health Status
}

\author{
Muhammad Hassan Danish ${ }^{1}$ and Hafeez ur Rehman Khan ${ }^{2}$
}

\begin{abstract}
Increase in social capital increases the social support in society, thus improves the health and well-being of an individual. This paper aims to analyze the role of social capital on subjective well-being (happiness, life satisfaction, and worth of life) and self-reported health status. The study deploys the Generalized Structural Equation Model with order logit to link social capital with health and subjective well-being (SWB) of people by utilizing the data of 1566 households and individuals in Punjab, Pakistan. Results of the study illustrate that social trust and the number of friends are strong predictors of self-reported health $(\mathrm{SRH})$ status and subjective well-being of people. While memberships with organizations or alike is a weak predictor of $S R H$, it significantly affects the happiness of people. Our results also depict that $S R H$ is the strong mediator between social capital and SWB; improved social networks lower the risk of poor health status, which improves the level of happiness and life satisfaction. The study suggests that a balanced distribution of different kinds of social networks is important for the self-reported health and subjective wellbeing of people in Pakistan.
\end{abstract}

Keywords: Health, Pakistan, Social Capital, Subjective Wellbeing

JEL Classification: A14, B55, I31

\section{Introduction}

Improving people's health and well-being is evolving as a key societal goal across the globe (Steptoe et al., 2015). In this regard, sustainable development goals (SDGs) also have a comprehensive world-wide agenda to shape the increasing development till 2030. Better health facilities, education, improving the environment, peace, justice, and institutional quality are among those factors which bring subjective well-being (Helliwell, 2003; Helliwell and Putnam, 2004; Ngamaba, 2017). For this purpose, efforts are being made to localize and prioritize the SDGs both at the national and regional level with a view to achieve the objectives of SDGs strategies at a fast track. Goal 10 also talks about reducing

\footnotetext{
${ }^{1} \mathrm{PhD}$ Scholar in National College of Business Administration and Economics \& Lecturer at University of Management \& Technology, Lahore.

${ }^{2}$ Professor of Economics, School of Business Economics, University of Management \& Technology, Lahore.

The paper is based upon first author's Ph.D. research work.

Corresponding author's Email: hassan.danish13@gmail.com; hassan.danish@umt.edu.pk
} 
inequality by empowering and promoting social, political, and economic inclusion for all, increasing the income of the poor population, and to ensure social protection policies to achieve equitable policies. Over the last two decades, the literature on social capital's impact on human health and well-being has also been growing and has gained popularity among economists, psychologists, and social and public health scientists (Coleman, 1988; Putnam, 1993; Sabatini, 2007; and Bartolini et $a l ., 2009)$. Despite being the sixth-largest populous country in the world, there is no evidence from Pakistan that social capital has a role to play in health and SWB. The present study is therefore being conducted to fill the gap in the literature and to examine the relationship between social capital and self-reported health (SRH) and subjective well-being (SWB) in Pakistan. Pakistan has shown significant improvement during the last four years in the ranking of happiness and its ranking is improved by 25 points from 2016 to 2019 which is the highest among South Asian Association for Regional Cooperation (SAARC) and the top twenty gainers among the world in 2019 (World Happiness Report, 2019) ${ }^{3}$. But it still needs improvement and this research intends to be helpful in determining the factors that raise or lessen the level of happiness or other factors of SWB. Results of this study will be helpful for policymakers to eradicate or control the factors which are responsible for low happiness level among people and thus SWB can be improved.

Social capital has been linked to productivity, economic development, wellfunctioning democracy, and safe and productive neighborhoods in the form of mutual trust. (Putnam, 1993, 2000; Fukuyama, 1995; Cook, 2000 and Stone et al., 2003). Moreover, health and well-being have also received considerable attention in the field of social capital (Putnam, 2000; Poortinga, 2006; Helliwell, 2006 and Yip et al., 2007; Hoffmann et al., 2019). There is increasing evidence on the positive impact of social capital on various aspects of people's physical and psychological health (e.g., Lomas, 1998; Hawe \& Schiell, 2000; Kawachi, et al., 1997, 1999, and Veenstra, 2000). Although it is now usually known that social networks are important for people's health and well-being, there is less debate over the specific nature of this relationship. For example, there is still a dearth in the literature to determine if social capital is a collective feature of peoples or societies, or if its useful properties relate to individuals and their social relations. (Kawachi et al., 2004).

The literature on social capital and health is also growing over the last few decades. But still, there is a dearth of literature to analyze the empirical relationship between social capital and SRH. Kawachi et al. (1997) found a positive relationship

\footnotetext{
${ }^{3}$ https://s3.amazonaws.com/happiness-report/2019/WHR19.pdf
} 
of mistrust and lack of assistance to the mortality rate in thirty-nine US States-while associations with different organizations/ institutions were inversely related to the cause-specific and overall mortality rate in the US. In a study of Chicago, the higher level of neighborhoods and social resources were also found to be positively associated with better self-reported health (Browning and Cagney, 2002; Wen et $a l ., 2003)$. On the other hand, research in the developed countries found that trust, membership, and civic engagement lower the rate of self-reported poor health (Kawachi et al., 1999, 2004) and increase the good SRH (Poortinga, 2006).

Very few studies are found in Pakistan, working in the context of SWB (see for example; Shams, 2014; Hasan and Khan, 2015; Hasan, 2016; Jabeen and Khan, 2016) but these studies have not considered the social capital and its importance in explaining the SWB and there is no consensus of research on social capital and health as well as its impact on SWB. In summary, this research builds on the existing literature by performing a cross-sectional analysis of individual's wellbeing in Pakistan, while considering SRH as a mediator. This paper will evaluate the following research questions;

1. What is the impact of social capital on SRH?

2. What is the mediating role of SRH on SWB?

3. What is the impact of demographics and other socio-economic variables on SWB?

\section{Theoretical foundation}

Everyone desires to be happy in life and to live in a happy society. Happiness is worth pursuing because it is spreadable and can spread among family, friends, neighbors, and relatives like flu (Fowler and Chistakis, 2008). Happiness affects human beings in numerous ways such as good mental and physical health, healthy and long life, and good human relations (Seligman and Royzman, 2003; Diener et al., 2003). Many evidences are available from developed and Western countries which acquire great progression in economic growth, but the people's happiness levels are not high. China is one amongst them, which ranks at number 86 in the world survey of happiness (World Happiness Report, 2018). Some arguments are given for such countries, that they may encounter a lot of social problems such as crime, stress, and intoxication which reduce their happiness levels (Layard, 2006). It has now become a fundamental concern of any government to improve the wellbeing of its citizens.

Many studies have already been carried out to support the link between social capital and the SWB (Helliwell, 2003; Vemuri and Costanza, 2006 Helliwell, 
2006; Fleche et al., 2011; Chang, 2009; Bartolini and Sarracino, 2014; Vega and Jesus, 2016; Ngamaba, 2017). Further, the literature on social capital and health is also growing in the last few decades (e.g. Kawachi et al., 1997; Ferlander, 2007). But there are still very few arguments in the literature to test the empirical relationship between social capital and SRH. All mentioned studies conclude that social capital improves self-reported health and reduces mortality, while very few of them discuss the association between social capital and SWB (e.g., Yip et al., 2007 and Tsuruta et al., 2019). However, there is still a gap in research on the indirect impact of social capital on SWB through health status. In a developing country like Pakistan, it is difficult to access government hospitals and to avail health facilities on time without societal support. So, social capital, in this context, is more helpful for any ill individual or household to approach health services easily and to improve the health status. More investment in social capital may help individuals in social support to access resources, which in turn promote their health and overall well-being (Putnam, 1993; Yip et al., 2007). This study, therefore, is designed to analyze the direct and indirect impact of social capital on SWB through the mediating effect of SRH.

The present study expands the model of the relationship between social capital and SWB of Vaughan et al. (1985), who measured SWB only through life satisfaction and social capital by "social support". We deploy three measures of SWB as well as of social capital, as discussed in section 3. The current model is an expansion of the study by Maass et al. (2016), who analyzed the impact of neighborhood social capital on life satisfaction and self-reported health (SRH) by using simple SEM, while the model employed in this study extends to GSEM ${ }^{4}$. This model contains the direct and indirect impacts of social capital on all measures of SWB and health status. Three measures of SWB are used in this study: happiness, life satisfaction, and worth of life. The basic framework of the theoretical and structural model is presented in Figure 1.

\footnotetext{
${ }^{4}$ GSEM is different from SEM as it also includes dummies and applies with ordinal variables, which is not applicable in SEM.
} 


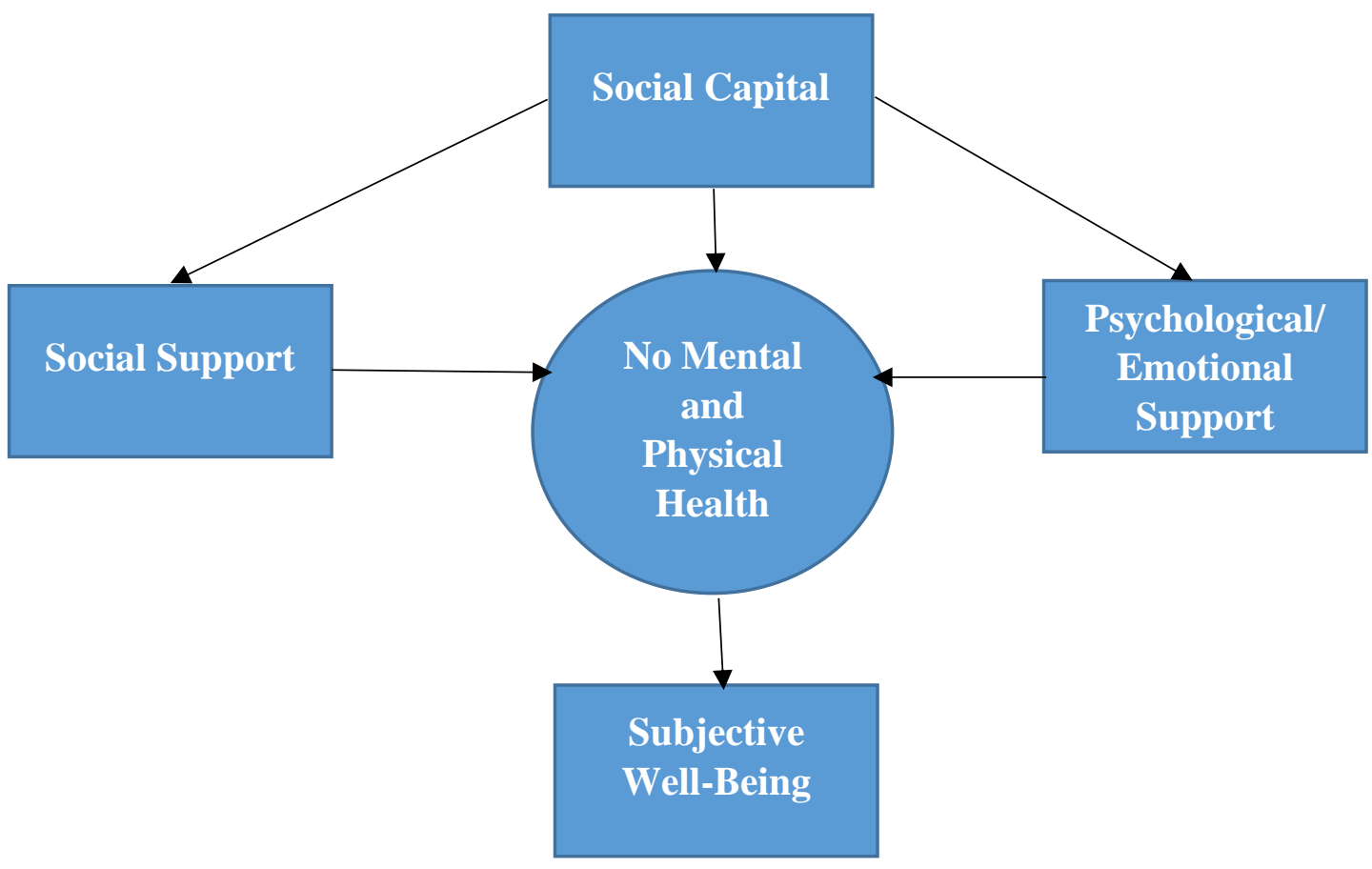

\section{Data and Method}

\subsection{Data Collection}

This study is based on primary data collected from individuals living in Lahore, Faisalabad, Multan, and Rawalpindi districts of Punjab, Pakistan. The rationale for selecting these four big districts is to cover the entire province of Punjab with heterogeneous characteristics of the sample population. The province Punjab is divided into three regions, namely Central, Southern and Northern Punjab. As more than $56 \%$ of the population is from central Punjab ${ }^{5}$, two districts (Lahore and Faisalabad) from central Punjab are selected. For similar reasons, the largest districts, Multan and Rawalpindi, are selected from the Southern and Northern Punjab respectively.

Four districts are divided further into different tehsils and then the respondents were selected from each stratum (tehsil) by random sampling from rural and urban areas. Sampling for this study is calculated based on the population

${ }^{5}$ Calculations are based upon population census, 2017. 
census (2017) for four districts under consideration. At the first stage, the total percentage sample for each district is determined by the following formula;

$$
\mathrm{n}=\frac{z^{2} P(1-P) N}{z^{2} P(1-P)+N e^{2}}
$$

In the first stage, the distribution of the sample is calculated for each district according to the weight calculated in step 1. In the second stage, stratified sampling is estimated for the distribution of sample among rural and urban areas for all districts according to the population proportion and finally, tehsil wise samples will be collected according to the population proportion of urban and rural areas by using the following formula;

$$
\mathrm{n}_{\mathrm{i}}=\frac{N_{i} * n}{N}
$$

For each district, half of the tehsils are selected for collecting the data based on major population proportion. Then the sample size for each tehsil is calculated based on the population proportion of rural and urban areas in respected tehsils. Lahore area is declared as 100\% urbanized in the population census, 2017, therefore, the sample will also be considered for an urban area in Lahore. The survey collects data on household composition, household's financial position, basic demographics, and a variety of social factors, governmental and institutional quality, and health-related indicators for each household member aged 20-80. The final sample consists of 1566 households consisting of both males (74\%) and females $(26 \%)$. The rrespondents were selected randomly according to sample design from the tehsils of each district (Lahore, Rawalpindi, Faisalabad, and Multan) and individuals were requested and interviewed to fill the required information in the questionnaire. Out of the total sample respondents (1566), almost 900 respondents were directly interviewed, while for the remaining sample, almost 1500 questionnaires were distributed, and the response rate was not more than 50\% on average. The data collection started in July 2018 and was completed in January 2019.

\subsection{Variables and Measures}

The present survey includes measures such as self-reported general health, happiness, life satisfaction, and worth of life. Explanatory variables include those related to demographic, social capital, government, and institutional quality, and other socioeconomic status of individuals. 


\subsubsection{Health and Subjective Well-Being}

To assess the self-reported health (SRH), the respondents were asked about their general health status on a 5-point Likert scale (All in all, how would you describe your state of health these days?), on which respondents evaluated their health from 'Very Good' (1) to 'Very Poor' (5). This measure has been used in various past studies and is considered as a valid measure of SRH (Helliwell and Putnam, 2004; Blanchflower and Oswald, 2008; Gwozdz and Sausa-Poza, 2010; Brown and Gray, 2016). Wellbeing, in most of the literature, has been investigated more generally in terms of life satisfaction (Helliwell, 2003; Baker et al., 2005; Yip et al., 2007). From that perception, well-being is a subjective phenomenon because this idea enables people to evaluate themselves in a way, they experience the degree of wellness, they feel. Maximizing one's well-being has also been regarded as one's highest feelings of happiness (Diener, 2000; Di Tella et al., 2003; Lenzen and Cummins, 2013; Mackerron and Mourato, 2013; Bartolini and Sarracino, 2014). Individuals might be satisfied with their lives, but might not be happy with their stressful lives (Greenfields and Marks, 2004). Self-evaluation of happiness generally turns out to be reflected in a short-run situation depending on the expression of mood, while self-reported life-satisfaction appears to be a more stable evaluation in assessing one's well-being (Helliwell and Putnam, 2004). According to Diener et al. (2003), happiness and life satisfaction are two different states of well-being and these two notions have frequently been interpreted as being hedonic, though there is a scope for a greater combination of SWB into a more eudemonic perspective (Deci and Ryan, 2008).

Previous studies have shown that SWB is measured by an individual's own cognitive assessment of life satisfaction as well as the evaluation through their moods and emotions, which economists and psychologist refer to as 'Happiness' (Diener, 2000; Helliwell and Putnam, 2004; Helliwell, 2006; Sarracino, 2013). But there is negligible consensus on measuring SWB through the worth of life. So, in the light of Dolan and Metcalfe (2012) and Deeming (2013), who advocate different measures and components of SWB distinctly, this study also suggests assessing each of "Eudemonic" (Worth-while), "Evaluation" (Life Satisfaction), and "Evaluative" (Happiness) measure separately. All measures of SWB are ordinally measured, scaling from 0 (not at all happy/satisfy/worth-while) to 10 (completely much happy/satisfy/worth-while) respectively. 


\subsubsection{Social capital}

Social capital has been defined in different ways by several economists. Glaeser et al. (1999) defined social capital as "Trust and trustworthiness" and Putnam $(1993,2001)$ defines it as the social network split into informal and formal social networks of friends, families, and organizations. Formal networks include community organizations such as trade associations and alike, while informal networks comprise of family members, friends, and neighbors, etc. Another economist, Sabatini (2007), divides social capital into three categories: bonding social capital of family, bridging the social capital of friends and neighbors, and linking social capital with voluntary organizations. In most of the literature, it is examined as "trust". Humans are social beings and trust is widely considered an important component in any social setting (Helliwell and Wang, 2011).

Putnam (1993), who focused on formal social networking, argued that it constitutes community skills and provides access to social resources, such as some kind of material support and assistance from various agencies and health care facilities for the provision of child care and medical services. However, informal networks of family, friends, and neighbors cannot be ignored in measuring social capital (Lin et al., 2001). For example, they are realized as the main source of social capital in Pakistan, especially while accessing job opportunities, good education, and medical facilities. Although social capital in previous researches is seen as a multidimensional concept, but amongst the variables of social capital used in World Value Surveys, economists considered a trust, informal networks of friends, and memberships with organization/associations as the most important indicators connected to social capital (e.g. Putnam, 1993; Kawachi et al.,1997; Knack and Keefer, 1997, Helliwell, 2006). These measures have also been used most commonly in studies of health outcomes and well-being (e.g. Kawachi et al., 1999, 2004; Browning and Cagney, 2002; Wen et al., 2003; Poortinga, 2006; Elgar et al., 2011; Bartolini and Sarracino, 2014; Maass et al., 2016). In the light of previous literature, this study advocates three measures of 'social capital': structural or formal social capital (measured by the number of memberships), the informal social capital of friends, and level of trust.

\subsubsection{Income and other Demographic Variables}

Using the methodology of Decancq and Lugo (2013) and Aristei and Bracalente (2011), this study calculates the equalized household income by taking family income from all sources and dividing it by the square root of the total number of household members. This method is adopted to compare the income at the household level with different individuals and accounts for economies of scale and 
household size, as resources of the household distributed among other family members. The equalized income of households is then converted into five quantiles from 1-5. Age and children are measured in five groups ${ }^{6}$, and females were coded as " 0 ", while males as " 1 ".

\subsubsection{Control Variables}

A standardized index of difficulties in approaching hospital services is constructed on the basis of problems faced by the respondent for getting health facilities. For this purpose, a three-point Likert scale was developed to ask the respondents about the problem; very difficult (1), a little difficult (2), and not at all difficult (3). Satisfaction with hospitals are categorized into two measures separately: satisfaction with government hospitals (SOGH) and with private hospitals (SOPH), which were asked from the respondents on a five-point Likert scale (very much $=1$ to not at all=5). Similarly, the respondents or their family members who visited the hospital during the last twelve months were also asked about the satisfaction with the operational services of hospitals, including skills and courtesy of staff, cleanliness, and treatment on a five-point Likert scale $(1=$ very dissatisfied and $5=$ very satisfied).

Some perceived factors of government effectiveness and institutional quality are also a part of the analysis in determining the SWB. A five-point Likert scale is developed for items of government effectiveness, which includes eight items (improving health services, protecting the environment, creating jobs, reducing inequality, fulfilling educational needs, fighting against corruption, improving infrastructure, providing electricity, gas, etc.). The performance of these items is evaluated from very poor (1) to very good (5). An index of government effectiveness is generated through PCA and factor loading, and outcome values are standardized to compare the individual SWB. Similarly, a four-point Likert scale is developed for satisfaction about the judiciary, police, and public institutions: not at all (1), not much (2), somewhat (3), and very much (4). These factors are used by the world value survey (WVS) and an index of institutional quality (IQI) is also constructed through PCA analysis after factor loading in SPSS and standardize against each value. The perception of corruption also affects SWB, as people do not feel worthy about their lives and values if government and institutions are involved in corruption. So, to capture this effect on wellbeing, the respondents were asked on the dichotomous scale, if the government is involved in corruption during the past 12 months. (Yes=1, No=0). The items used by ICRG to construct the corruption perception index were also asked if the respondent has replied "Yes" to

${ }^{6}$ For details, see appendix A. 
the previous question. However, the index is not used in the analysis as it affected the robustness of the whole model and other variables and it was also not significant with any measure of SWB.

\subsection{Methods and Statistical Analyses}

In the first stage of analysis, the socio-demographics of the sample are described to view the sample data. For this purpose, a descriptive analysis of certain variables, including gender, age, income, social capital, employment status, and institutional satisfaction is provided. After the descriptive analysis, the study employed a generalized structural equation model (GSEM) to determine the direct and indirect effects of social capital on SWB, where the SRH is used as a mediator with some control variables like age, gender, income, and children. In addition, other variables are also used as control variables in the analysis for the robustness check and are used in groups step by step, and the results are reported in the appendices. ${ }^{7}$ In model 1, only demographic variables are included, while households and personal financial variables are included in model 2. Model 3 and 4 include variables such as institutional quality and personal life experiences and perceptions. Finally, all the variables are regressed over SWB and the results are reported in table 3.

As discussed earlier, in developing countries like Pakistan, without societal support, it is difficult to access government hospitals and to avail health facilities on time. So, social capital in this context is more helpful for any ill individual or household to approach health services easily and to improve the health status. Therefore, more investment in social capital may help individuals in social support to access resources, which in turn promote their health, and good health is the key indicator of subjective well-being (Putnam, 1993; Yip et al., 2007). Therefore, this paper deploys the mediation effect of SRH between social capital and SWB.

Figure 2

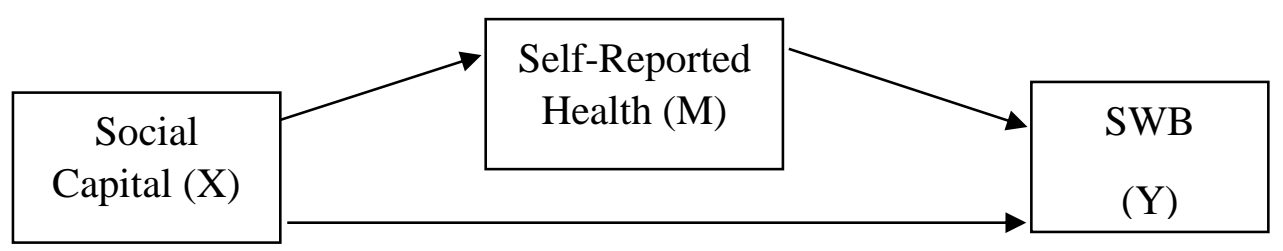

${ }^{7}$ Variables include satisfaction with hospitals, marital status, employment status, loan, agri-land, political interest, safety measures, worrisome on terrorism, corruption perception, government effectiveness, institutional quality and satisfaction with services of hospitals are discussed in results part in detail and results are reported in Appendix. 


$$
\begin{gathered}
S R H_{i}^{*}=\beta_{0}+\beta_{1} N O F_{i}^{*}+\beta_{2} M E M_{\cdot i}^{*}+\beta_{3} T 1_{i}^{*}+\beta_{4} T 2_{i}^{*}+\beta_{5} T 3_{i}^{*}+\beta_{6} T 4_{i}^{*} \\
+\beta_{7} X_{i}^{*}+\mu_{i} \\
S_{i}=\gamma_{o}+\gamma_{1} S R H_{i}+\gamma_{2} Z_{i}+\omega_{i}
\end{gathered}
$$

Where, $\mathrm{i}=1,2,3, \ldots \ldots, \mathrm{k}$ individuals. SRHi*is the outcome of the selfreported health status of individuals and $X_{i}^{*}$ is the vector of demographic determinants of SRH. While, 'NOF', 'Mem'., and ' $T$ ' represent the informal network of friendship, memberships with associations or alike, and categories of trusts $^{8}$ respectively in equation 3 . These variables of interest were also used by Bjornskov (2008) to analyze the impact of social capital on happiness in the United States. $\mathrm{Si}$ is the SWB, measure by three approaches including; Eudemonic, Evaluation, and Hedonic measure as discussed above, and all measures are regressed over social capital and health separately in each model. $\mathrm{Zi}$ in equation 4 is the vector of demographic and other socio-economic variables, which include; gender, employment status, marital status, land ownership, loan, satisfaction with hospital services, freedom, political interest, security adaptation, crime victim, institutional quality, government effectiveness, and corruption.

Moreover, all continuous variables are standardized to compare the values of the coefficient more precisely and easily. As all the dependent variables (SRH and SWB) in our model are of ordinal outcomes from 0 to 10, so an appropriate method for analyzing such models is ordered logistic (Cameron and Trivedi, 1986). The estimation technique used by Yip et al. (2007) was separately for self-reported health and well-being with the regressor of social capital and an ordered logistic model was applied in their analysis. Similarly, Vaughan et al. (1985) and Maass et al. (2016) applied SEM analyses for the same kind of analysis but our model is distinguishing from previous studies, as it applies GSEM with order logit model. GSEM allows multi-level models and factor-variable notation to be used in requiring models that SEM does not. As the mediating variable $(\mathrm{SRH})$ and the outcome variable (SWB) in this study are ordinal in the outcome, so we can use ordered probit or ordered logit models in the GSEM framework to deal with variables. Ordered logit yields almost identical results while making use of the logistic distribution. Order logit produces a prediction about the probabilities that a respondent gives a response from $0,1,2, \ldots ., 10$. It follows the normal distribution into $\mathrm{k}$ categories divided by ' $\mathrm{k}-1$ ' cut-points $\left(\mathrm{c}_{1}, \mathrm{c}_{2}, \ldots, \mathrm{c}_{\mathrm{k}-1}\right)$. We assume that each respondent has a score;

${ }^{8}$ See Appendix for Variables Description 
$\delta=\beta X+\varepsilon$, with the standard normal distribution of $\varepsilon$, and this score is used with the cutpoints to measure probabilities for each of the respondents.

$$
\operatorname{Pr}(\mathrm{i} \mid \mathrm{X})=\operatorname{Pr}\left(\mathrm{c}_{\mathrm{i}-1}<\beta X+\varepsilon \leq \mathrm{c}_{\mathrm{i}}\right.
$$

Where $c_{1}, c_{2}, \ldots, c_{k-1}$, and $\beta$ are the parameters in the model to be fit through SEM.

\section{Results and Discussion}

Descriptive statistics of the sample study have been presented in table 1 . The sample study consists of $26 \%$ of females and $74 \%$ males. The mean age of the sample study is 39 years, while mean education and family sizes have been recorded as 12 years and 6.46 respectively. Almost 56\% of sample respondents have an average per-capita household income up to Rs. 30000 and only $24 \%$ have a per-capita household income above Rs.45000. Up to $43.5 \%$ of respondents reported their health status as good, while a few people reported their health status as poor or very poor (5.7\% and $1.9 \%$ respectively). Only a few respondents are satisfied with police, judiciary, and public institutions and this variation lie between only $6 \%$ to $16 \%$ for very much satisfaction. About $16 \%$ of respondents think that there is no corruption in public institutions and governing bodies, while negative reporting about corruption was high up to $84 \%$ (Table 1).

Table 1: Descriptive Statistics

\begin{tabular}{lcc}
\hline & Variables & Proportion (\%) \\
\hline Gender (n=1566) & Male & 74.2 \\
& Female & 25.8 \\
Age (n=1566) & & \\
& Up to 25 & 14.1 \\
& $26-35$ & 33.7 \\
& $36-45$ & 21.1 \\
& $46-55$ & 21.8 \\
Marital Status (n=1566) & above 55 & 9.3 \\
& Single & 28.4 \\
& Married & 68.3 \\
& Widowed & 2.6 \\
& Others & .6
\end{tabular}

Education $(n=1566)$ 
Social Capital as a Resource of Subjective Well-Being: Mediating Role of Health Status

$\begin{array}{cc}\text { Primary or Below } & 5.2 \\ \text { Secondary } & 7.3 \\ \text { Matric } & 14.0 \\ \text { Intermediate } & 11.1 \\ \text { Bachelor } & 19.9 \\ \text { Masters } & 25.7 \\ \text { MPhil or Above } & 10.2 \\ \text { Others } & 2.0\end{array}$

Employment Status ( $\mathrm{n}=1566)$

$\begin{array}{cc}\text { Full Time } & 52.4 \\ \text { Part-Time } & 8.6 \\ \text { Self Employed } & 20.0 \\ \text { Retired } & 4.7 \\ \text { Unemployed/Housewife } & 14.3\end{array}$

Income ( $\mathrm{n}=1566)$

$\begin{array}{cc}\text { up to } 15000 & 21.3 \\ 15001-30000 & 34.5 \\ 30001-45000 & 19.3 \\ 45001-60000 & 8.8 \\ >60000 & 16.1\end{array}$

Health Status $(\mathrm{n}=1566)$

$\begin{array}{cc}\text { Very Good } & 24.5 \\ \text { Good } & 43.5 \\ \text { Fair } & 24.4 \\ \text { Poor } & 5.7 \\ \text { Very Poor } & 1.9\end{array}$

Services of Government Hospital $(\mathrm{n}=1201)$

$\begin{array}{cc}\text { Very Much } & 7.8 \\ \text { Somewhat } & 24.7 \\ \text { Neutral } & 27.3 \\ \text { Not Much } & 25.5 \\ \text { Not at all } & 14.7\end{array}$

Services of Private Hospital $(\mathrm{n}=1201)$

$\begin{array}{cc}\text { Very Much } & 26.0 \\ \text { Somewhat } & 35.2 \\ \text { Neutral } & 24.6 \\ \text { Not Much } & 8.4\end{array}$


Satisfy with Judiciary $(\mathrm{n}=1566)$

$\begin{array}{cc}\text { Not at all } & 22.7 \\ \text { Not Much } & 25.9 \\ \text { Somewhat } & 35.1 \\ \text { Very Much } & 16.3\end{array}$

Satisfy with Police $(\mathrm{n}=1566)$

Not at all $\quad 42.3$

Not Much 33.1

Somewhat 21.4

Very Much $\quad 3.3$

Not at all $\quad 17.8$

Not Much $\quad 32.6$

Somewhat $\quad 42.8$

Very Much $\quad 6.8$

Corruption Perception $(\mathrm{n}=1566)$

Memberships $(\mathrm{n}=1566)$

$\begin{array}{lr}\text { NO } & 45.5 \\ \text { Yes } & 54.5\end{array}$

Trust on Family $(\mathrm{n}=1564)$

$$
\text { Completely }
$$

Not at all

Trust on Neighbours $(n=1562)$

$\begin{array}{cc}\text { Completely } & 24.9 \\ \text { Somewhat } & 48.7 \\ \text { Not Very Much } & 20.4 \\ \text { Not at all } & 6.0\end{array}$

Trust on Friends $(n=1563)$

$$
\text { Completely }
$$


Trust on People $(\mathrm{n}=1559)$

\begin{tabular}{cc} 
Completely & 6.3 \\
Somewhat & 15.4 \\
Not Very Much & 34.4 \\
Not at all & 43.6 \\
\hline
\end{tabular}

Source: Author's calculations

\subsection{GSEM Analyses}

GSEM analysis with odd ratios is reported in Table 2 to develop a structural relationship between social capital and SWB via health status. In these models, trust in friends and neighbors seemed to be a strong predictor of SRH among individuals. The lower level of trust in neighbors significantly increases the odds of poor SRH by 1.60 and mistrust on friends by 0.11 (Kawachi et al., 1997; Wen et al., 2003 and Yip et al.,2007). Contrary to the research of Yip et al. (2007), more memberships with associations also increase the odds towards poor SRH by $0.21(\mathrm{p}<0.1)$ but in the case of developed countries, it is positively associated with poor health (Kawachi et al., 1999). More close friendships of an individual improve the SRH, but statistically, this relationship is weak $(\mathrm{OR}=0.90 ; \mathrm{p}<0.1)$. The present study also shows that social networks have a negative association with a poorer state of health, which means that chances of poor health status decline with the increased number of social networks. The previous study shows a positive association of social networks with better-reported health in Chicago (Browning and Cagney, 2002). Moreover, according to the study of Kawachi et al. (1999), age and income have linear and strong relationships with the SRH of people. Health status becomes significantly poor in old age or as the age increases. The odds of being a poor SRH increase by 1.54 points, while moving the age from 25 to the group of people with the age of more than 55. While an increase in income lowers the odds of poor health among individuals and it significantly lower the odds of poor SRH among the top income group by 0.51 odds with the reference group (lower-income quantile).

Results of the structural model show that health is an important factor for all SWB measures and significantly reduces SWB if health is not good or poor. Poor health significantly drops down the level of happiness, life satisfaction, and worth of life at the $1 \%$ level of confidence $(p<0.01)$. A study by Helliwell (2006) on WVS data demonstrated that good health status is negatively related to suicide rate and positively related to life satisfaction. Wunder et al. (2013) found that disability and night stayed at hospital decreases the probability of life satisfaction in Germany. Moreover, happiness along with life satisfaction is also found to be high with good health status in many studies (Yip et al., 2007; Knabe et al., 2010; Fleche et al., 2011; Knol and Pitlik, 2015; Ngamaba, 2016; Vega and Jesus, 2016). 
Table 2: Structural Equational Model for the Association Between Social Capital and SWB: Mediating Role of SRH (Very Good to Very -Poor)

\begin{tabular}{|c|c|c|c|c|}
\hline Variables & Health-Status & Happiness & Life Satisfaction & Worth-While \\
\hline & (Baseline) & (1) & (2) & (3) \\
\hline & Odd Ratios & Odd Ratios & Odd Ratios & Odd Ratios \\
\hline \multirow[t]{2}{*}{$\begin{array}{l}\text { Health-Status } \\
\text { Good }\end{array}$} & & $0.51^{* * *}$ & $0.47^{* * * *}$ & $0.54 * * *$ \\
\hline & & $(0.06)$ & $(0.06)$ & $(0.06)$ \\
\hline \multirow[t]{2}{*}{ Fair } & & $0.24 * * *$ & $0.28 * * *$ & $0.37 * * *$ \\
\hline & & $(0.03)$ & $(0.04)$ & $(0.05)$ \\
\hline \multirow[t]{2}{*}{ Poor } & & $0.14^{* * *}$ & $0.19 * * *$ & $0.24 * * *$ \\
\hline & & $(0.03)$ & $(0.04)$ & $(0.05)$ \\
\hline \multirow[t]{2}{*}{ Very Poor } & & $0.06^{* * * *}$ & $0.10 * * *$ & $0.21 * * *$ \\
\hline & & $(0.02)$ & $(0.04)$ & $(0.08)$ \\
\hline \multicolumn{5}{|l|}{ Age } \\
\hline \multirow[t]{2}{*}{$26-35$} & 0.96 & $0.63 * * *$ & 0.85 & 0.80 \\
\hline & $(0.16)$ & $(0.10)$ & $(0.13)$ & $(0.12)$ \\
\hline \multirow[t]{2}{*}{$36-45$} & 1.38 & $0.69 *$ & 0.97 & 0.84 \\
\hline & $(0.30)$ & $(0.14)$ & $(0.20)$ & $(0.17)$ \\
\hline \multirow[t]{2}{*}{$46-55$} & $2.45^{* * *}$ & $0.65 * *$ & 1.25 & 1.10 \\
\hline & $(0.55)$ & $(0.14)$ & $(0.26)$ & $(0.23)$ \\
\hline \multirow[t]{2}{*}{$>55$} & $2.54 * * *$ & $0.53 * * *$ & 1.15 & 0.96 \\
\hline & $(0.66)$ & $(0.13)$ & $(0.28)$ & $(0.23)$ \\
\hline \multirow[t]{2}{*}{ Number of Friends } & $0.90 *$ & $1.15^{* *}$ & $1.24 * * *$ & $1.12 * *$ \\
\hline & $(0.05)$ & $(0.06)$ & $(0.08)$ & $(0.07)$ \\
\hline \multirow[t]{2}{*}{ Memberships: Yes } & $1.21 *$ & $1.28 * *$ & 1.10 & 1.09 \\
\hline & $(0.13)$ & $(0.13)$ & $(0.11)$ & $(0.11)$ \\
\hline \multicolumn{5}{|l|}{ Family Trust } \\
\hline \multirow[t]{2}{*}{ Somewhat } & 1.01 & $0.64 * * *$ & 0.79 & $0.67 * * *$ \\
\hline & $(0.17)$ & $(0.10)$ & $(0.12)$ & $(0.10)$ \\
\hline \multirow[t]{2}{*}{ Not Much } & 0.91 & $0.41 * * *$ & $0.40 * * *$ & $0.54 * *$ \\
\hline & $(0.28)$ & $(0.11)$ & $(0.11)$ & $(0.15)$ \\
\hline \multirow[t]{2}{*}{ Not at all } & 1.14 & $0.27 * * *$ & $0.47 * *$ & $0.43 * *$ \\
\hline & $(0.39)$ & (0.09) & $(0.15)$ & $(0.14)$ \\
\hline \multicolumn{5}{|l|}{ Neighbour's Trust } \\
\hline \multirow[t]{2}{*}{ Somewhat } & $1.71 * * *$ & 1.14 & $0.81 *$ & 0.86 \\
\hline & $(0.22)$ & $(0.14)$ & $(0.10)$ & $(0.11)$ \\
\hline Not Much & $1.93 * * *$ & 1.12 & 0.89 & 1.01 \\
\hline
\end{tabular}




$\begin{array}{ccccc} & (0.31) & (0.17) & (0.13) & (0.15) \\ \text { Not at all } & 2.60 * * * & 1.39 & 0.80 & 0.90 \\ & (0.63) & (0.32) & (0.18) & (0.20)\end{array}$

Friend's Trust

Somewhat

$1.25^{*}$

$0.69 * * *$

$0.66 * * *$

$0.66^{* * *}$

(0.15)

(0.08)

(0.07)

(0.07)

Not Much

$1.47 * *$

$0.45^{* * *}$

(0.23)

(0.07)

$0.43^{* * * *}$

$0.40^{* * *}$

Not at all

1.11

$0.38^{* * *}$

(0.07)

(0.06)

(0.26)

(0.08)

$0.43^{* * * *}$

$0.40 * * *$

(0.10)

(0.09)

People's Trust

Somewhat

0.81

0.77

1.03

0.87

(0.19)

(0.17)

(0.24)

(0.20)

Not Much

0.96

0.68 *

0.96

0.90

(0.21)

(0.15)

(0.21)

(0.19)

Not at all

0.90

$0.65^{* *}$

0.93

0.96

(0.20)

(0.14)

(0.20)

(0.21)

Income

15001-30000

0.97

$2.88 * * *$

$2.00 * * *$

$2.02 * * *$

(0.13)

(0.39)

(0.27)

(0.27)

30001-45000

$0.75^{*}$

$3.94 * * *$

$2.35 * * *$

$2.49 * * *$

(0.12)

(0.61)

(0.36)

(0.38)

45001-60000

$0.65 * *$

$6.02 * * *$

$3.46 * * *$

$3.04 * * *$

(0.13)

(1.15)

(0.65)

(0.57)

$0.49 * * *$

$7.75^{* * *}$

3.84 ***

$3.60 * * *$

(0.09)

(1.31)

(0.64)

(0.60)

Children Dummy

Yes

Yes

Log-Likelihood

$-8050.06$

Yes

Yes

Observations 1537

$-7890.38$

$-8133.36$

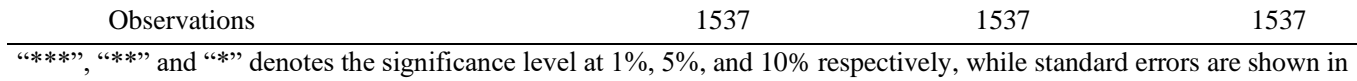
parenthesis.

Social capital, although, has a very weak impact on health status, but strongly affects the SWB of an individual. Humans are social beings and trust is widely considered an important component in any social setting (Helliwell and Wang, 2011). The results of the present study are also consistent with previous studies of Graham (2011) and Fleche et al. (2011), as more close friends increase the happiness by odds of $0.15(\mathrm{p}<0.05)$, LS by $0.24(\mathrm{p}<0.01)$ and worthwhile by 0.12 odds $(\mathrm{p}<0.05)$. Similarly, memberships with one or more than one association 
Table 3: Structural Equation Model of Control Variables for the Association Between Social Capital and SWB: Mediating Role of Self-Reported Health Status (Very Good to Very Poor)

\begin{tabular}{|c|c|c|c|}
\hline & Happiness & Life Satisfaction & Worth-While \\
\hline & Odd Ratios & Odd Ratios & Odd Ratios \\
\hline \multirow[t]{2}{*}{ Gender: Female } & 1.12 & 0.97 & 1.08 \\
\hline & $(0.13)$ & $(0.12)$ & $(0.13)$ \\
\hline \multicolumn{4}{|l|}{ Education } \\
\hline \multirow[t]{2}{*}{ Primary or Below } & 1.05 & 1.58 & 1.08 \\
\hline & $(0.31)$ & $(0.48)$ & $(0.32)$ \\
\hline \multirow[t]{2}{*}{ Secondary } & 0.95 & $1.62 *$ & 0.77 \\
\hline & $(0.27)$ & $(0.47)$ & $(0.22)$ \\
\hline \multirow[t]{2}{*}{ Matric (10 Years) } & $1.86^{* *}$ & $1.90 * *$ & 1.39 \\
\hline & $(0.48)$ & $(0.50)$ & $(0.36)$ \\
\hline \multicolumn{4}{|l|}{ Intermediate (12 } \\
\hline \multirow[t]{2}{*}{ Years) } & $3.13 * * *$ & $3.44 * * *$ & $1.71 * *$ \\
\hline & $(0.84)$ & $(0.94)$ & $(0.46)$ \\
\hline \multirow[t]{2}{*}{ Bachelor (14 Years) } & $3.46^{* * *}$ & $3.35 * * *$ & $1.59 *$ \\
\hline & $(0.88)$ & $(0.87)$ & $(0.41)$ \\
\hline \multirow[t]{2}{*}{ Masters (16 Years) } & $4.68 * * *$ & $3.56^{* * * *}$ & $2.17 * * *$ \\
\hline & $(1.20)$ & $(0.93)$ & $(0.56)$ \\
\hline \multicolumn{4}{|l|}{ MPhil or above (18 } \\
\hline \multirow[t]{2}{*}{ Years or more) } & $5.38 * * *$ & $3.79 * * *$ & $2.39 * * *$ \\
\hline & (1.49) & (1.07) & $(0.67)$ \\
\hline \multirow{3}{*}{$\begin{array}{l}\text { Certification/ } \\
\text { Engineer/Medical }\end{array}$} & & & \\
\hline & $5.95^{* * *}$ & $6.67 * * *$ & $4.48 * * *$ \\
\hline & $(2.31)$ & $(2.61)$ & $(1.75)$ \\
\hline \multicolumn{4}{|l|}{ Employment Status } \\
\hline \multirow[t]{2}{*}{ Part Time } & $0.55^{* * *}$ & $0.71 * *$ & $0.74 *$ \\
\hline & $(0.09)$ & $(0.12)$ & $(0.13)$ \\
\hline \multirow[t]{2}{*}{ Self-Employed } & $1.27 *$ & 1.04 & 1.08 \\
\hline & $(0.16)$ & $(0.13)$ & $(0.14)$ \\
\hline \multirow[t]{2}{*}{ Retired } & 0.74 & 0.96 & $0.58 * *$ \\
\hline & $(0.18)$ & $(0.23)$ & $(0.14)$ \\
\hline \multirow[t]{2}{*}{ Unemployed } & 1.15 & 1.20 & 1.07 \\
\hline & $(0.17)$ & $(0.18)$ & $(0.16)$ \\
\hline \multicolumn{4}{|l|}{ Marital Status } \\
\hline \multirow[t]{2}{*}{ Married } & $1.34 * * *$ & $1.37 * * *$ & $1.30 * *$ \\
\hline & $(0.15)$ & $(0.15)$ & $(0.14)$ \\
\hline \multirow[t]{2}{*}{ Widowed } & 0.64 & 0.67 & 0.93 \\
\hline & $(0.21)$ & $(0.21)$ & $(0.29)$ \\
\hline
\end{tabular}


Social Capital as a Resource of Subjective Well-Being: Mediating Role of Health Status

\begin{tabular}{|c|c|c|c|}
\hline Divorced & $\begin{array}{l}0.64 \\
(0.35)\end{array}$ & $\begin{array}{c}0.30^{* *} \\
(0.16)\end{array}$ & $\begin{array}{c}0.74 \\
(0.40)\end{array}$ \\
\hline Residence: Rented & $\begin{array}{c}1.08 \\
(0.13)\end{array}$ & $\begin{array}{l}0.99 \\
-0.12\end{array}$ & $\begin{array}{c}1.18 \\
(0.14)\end{array}$ \\
\hline Agri-land: Yes & $\begin{array}{c}1.43^{* * * *} \\
(0.16)\end{array}$ & $\begin{array}{c}1.50^{* * *} \\
(0.16)\end{array}$ & $\begin{array}{l}1.25^{* *} \\
(0.13)\end{array}$ \\
\hline Loan: Yes & $\begin{array}{c}0.63^{* * * *} \\
(0.08)\end{array}$ & $\begin{array}{c}0.68^{* * *} \\
(0.08)\end{array}$ & $\begin{array}{l}0.80 * \\
(0.10)\end{array}$ \\
\hline $\begin{array}{l}\text { Satisfaction index with } \\
\text { Hospitals }\end{array}$ & $\begin{array}{l}1.09 * \\
(0.05)\end{array}$ & $\begin{array}{l}1.09^{*} \\
(0.05)\end{array}$ & $\begin{array}{c}1.08 \\
(0.05)\end{array}$ \\
\hline $\begin{array}{l}\text { Barriers in } \\
\text { approaching Hospitals }\end{array}$ & Yes & Yes & Yes \\
\hline Barriers*Friends & $\begin{array}{l}1.14^{* *} \\
(0.07)\end{array}$ & $\begin{array}{c}1.20^{* * *} \\
(0.08)\end{array}$ & $\begin{array}{c}1.03 \\
(0.06)\end{array}$ \\
\hline Institutional Quality & $\begin{array}{l}1.10^{* *} \\
(0.05)\end{array}$ & $\begin{array}{c}1.07 \\
(0.05)\end{array}$ & $\begin{array}{c}1.08 \\
(0.05)\end{array}$ \\
\hline $\begin{array}{l}\text { Government } \\
\text { Effectiveness }\end{array}$ & $\begin{array}{c}1.08 \\
(0.05)\end{array}$ & $\begin{array}{l}1.10^{* *} \\
(0.05)\end{array}$ & $\begin{array}{l}1.10 * * \\
(0.05)\end{array}$ \\
\hline Corruption: No & $\begin{array}{c}1.41^{* * *} \\
(0.18)\end{array}$ & $\begin{array}{l}1.33^{* *} \\
(0.17)\end{array}$ & $\begin{array}{l}1.28 * \\
(0.16)\end{array}$ \\
\hline Security Adaptation & $\begin{array}{c}0.89^{* *} \\
(0.04)\end{array}$ & $\begin{array}{c}0.90^{* *} \\
(0.04)\end{array}$ & $\begin{array}{l}0.89 * * \\
(0.04)\end{array}$ \\
\hline $\begin{array}{l}\text { Worrisome on } \\
\text { Terrorism }\end{array}$ & $\begin{array}{l}0.93 * \\
(0.04)\end{array}$ & $\begin{array}{c}0.91^{* *} \\
(0.04)\end{array}$ & $\begin{array}{l}1.02 \\
(0.05)\end{array}$ \\
\hline Freedom & $\begin{array}{c}1.45^{* * * *} \\
(0.03)\end{array}$ & $\begin{array}{c}1.56^{* * *} \\
(0.04)\end{array}$ & $\begin{array}{c}1.50^{* * * *} \\
(0.04)\end{array}$ \\
\hline Political Interest & Yes & Yes & Yes \\
\hline $\begin{array}{l}\text { Crime: Yes } \\
\text { Satisfaction with } \\
\text { Government Hospitals } \\
\text { Satisfaction with }\end{array}$ & $\begin{array}{l}\text { Yes } \\
\text { Yes }\end{array}$ & $\begin{array}{l}\text { Yes } \\
\text { Yes }\end{array}$ & $\begin{array}{l}\text { No } \\
\text { Yes }\end{array}$ \\
\hline $\begin{array}{l}\text { Private Hospitals } \\
\text { Log Likelihood }\end{array}$ & $\frac{\text { Yes }}{-8050.06}$ & $\frac{\text { Yes }}{-7887.98}$ & $\frac{\text { Yes }}{-8133.12}$ \\
\hline Observations & 1537 & 1537 & 1537 \\
\hline
\end{tabular}

“***”, “**”, and “** denotes the significance level at 1\%,5\%, and 10\% respectively, while Standard Errors are shown in parenthesis.

also increase the odds of SWB but this relationship is not strong and significant only in the happiness model $(\mathrm{OR}=1.28 ; \mathrm{p}<0.05)$. These results show that 
networking with others often improves as people are involved in voluntary associations. This rise in networking contributes to mutual trust and communication, and above all helps to solve each other's problems that make them happy and satisfied with life (Helliwell and Putnam, 2004; Helliwell, 2006; Bartolini and Sarracino, 2014 \& Rodriguez-Pose and Von-Berlepsch, 2014).

Trust is also found to be a significant contributor to the well-being of people. The lower level of trust also decreases the odds of SWB and vice versa (Chang, Mackerron, and Mourato, 2009). The results of the study also explore that a lower level of trust with family and friends reduces the level of happiness by odds of 0.73 and 0.62 respectively $(\mathrm{p}<0.01)$. Bjornskov (2003) explored a significant relationship between trust and life happiness in country-level regressions. Mistrust in family and friends also significantly decreases the level of LS and worthwhile. Bjornskov (2008) found a significant relationship between LS and social trust in the US. However, Ram (2010) noted only a minor role for social trust in life satisfaction in country-level regressions.

Old age people are happier, more satisfied with their lives, and feel more worthwhile about their lives than the youth-Aging also has a significant relationship with happiness. Blanchflower and Oswald (2008) found a U-shaped relationship between age and happiness, but this relationship was not statistically significant in the US people from the age of 20-29 and above 60. Several studies, in recent years, have identified a U-shaped relationship of age to happiness and life satisfaction. These studies reported a number of reasons for this observation, one of the most interesting reasons are that younger people have higher expectations in their lives than the old, which are not met. While, older people have experience of life to adopt realistic aspirations (Frey and Stutzer, 2000; Helliwell and Putnam, 2004; Graham, 2011; Helliwell and Wang, 2011; Ngoo et al., 2015; Ngamaba, 2016). The present study shows the least happiness among older age above, which may be due to the poor health status in this age group of people.

SWB becomes stronger when people are happy with their family income. The relationship of income with happiness and LS are very known in the literature, and most of the studies found a positive and significant impact of income on SWB (Di Tella et al., 2003; Helliwell, 2003; Alesina et al., 2004; Dorn et al., 2007; Deeming, 2013; Brown and Gray, 2016). The present study also shows that the odds of all measures of SWB increase significantly with an increase in income level. The larger effect in the change of income is seen in happiness, where the odds of happiness among the top income group are more than twice than the income group of the second quantile $(\mathrm{OR}=7.75 ; \mathrm{p}<0.01)$. Life satisfaction is also on the 
higher side by odd of 2.84 among the top income group than the lower income group $(\mathrm{OR}=3.84 ; \mathrm{p}<0.01)$ and worth of life increases by 2.60 odds $(\mathrm{OR}=3.60$; $\mathrm{p}<0.01)$ than the reference group. The number of children is neither significantly related to health status nor with measures of SWB but an increase in the number of children increases the odd towards poor health status and lowers the SWB.

There are also some other variables, related to personal life, which are regressed separately at the first step, then regressed over SWB with all variables. Amongst these variables, the people who were worried about terrorism and war reported less happiness and LS. Crime not only discourages investment but also creates uncertainty and inefficiency (Detotto and Otranto, 2010). Similarly, individuals or households who adopt security measures or feel insecure while going outside, either alone or with family, their happiness and LS also decreases significantly. Moreover, for the people who feel free about their lives and choices, there is considerable improvement in their SWB, happiness, LS. Further, the worth of life also gets increased, and this relationship is statistically robust among all personal life experiences ( $\mathrm{p}<0.01$ ). These results are also consistent with findings at the national level (Hasan and Khan, 2015) and international level (Fleche et al., 2011; Ngamaba, 2016). Institutional quality is positively related to level of happiness $(O R=1.10 ; \mathrm{p}<0.05)$ and worth of life $(\mathrm{OR}=1.08 ; \mathrm{p}<0.10)$. Trust in police increases happiness among nations (Helliwell and Putnam, 2004). For people who perceived no corruption, their happiness also increases by odds of 0.41 ( $p$ $<0.01$ ). These results are consistent with the study of Bjornskov (2003), who found that perceived corruption in America, Europe, and Asia lower the happiness level among society. Finally, the results did not find any statistically significant relationship of political interest with SWB.

\section{Conclusion}

An increase in social capital may increase the social support in society, and thereby improve the health and well-being of an individual. Social capital constitutes a connection with social groups, a sense of civic responsibility and reciprocity. Keeping in view, the present study has employed Generalized Structural Equation Model with order logit to link social capital with health and SWB of people by utilizing the data of 1566 households and individuals in the Punjab, Pakistan. Societal well-being is now being increasingly recognized as a way to achieve economic development goals. Especially in underdeveloped countries like Pakistan, it has now become the desired campaign to improve the well-being and prosperity of its people. This study has contributed to an improved understanding of the subject by developing a framework that can assist 
policymakers and government to work on the areas that can improve the overall well-being of people. Results of the study confirm that health status is a strong mediator between social capital and SWB. The informal network of friends lowers the ratio of poor SRH and increases SWB. Similarly, the lower the level of trust in friends and neighbors, the higher the ratio of poor SRH and vice versa. However, memberships of institutions/organizations and friendship networks have a weak relation with SWB, but these are the strongest predictors of SWB directly. Happiness and life satisfaction increase with an increase in the number of friends and voluntary associations. Trust in family and friends also contributes significantly towards individual wellbeing, as the analysis of the present study reveals that mistrust causes lower SWB. The study also points out that people who have difficulties in accessing hospital services but have strong social connections, are happier, satisfied, and feel worthy about their lives. The results also confirm that the people who are satisfied with institutions, government, and services of the hospital and who have strong social ties and support, have better wellbeing than those people who are not satisfied with institutions and government. The study suggests the balanced distribution of different kinds of social networks, because it benefits both individuals and public health simultaneously, as social capital encompasses by the high level of support from society, provide accessibility and empower people in the society. Moreover, the government institutions would be beneficial for raising wellbeing not only at an individual level, but also at a national level, and in this context, control of corruption should be the national agenda, as Pakistan is ranked at 117 in the corruption index out of 175 countries (ICRG, 2018). Corruption and poor institutional quality are the main problems of society that do not provide support to society and hence affect their psychological and physical well-being. Because this study used primary data and lacks funding for surveys, it is restricted to four districts of Punjab, which can be expanded with these factors all over the Punjab or Pakistan. Furthermore, it can also be expanded towards the two-way link between SC and SRH. 


\section{References}

Alesina, A., Di Tella, R., \& MacCulloch, R. (2004). Inequality and happiness: Are Europeans and Americans different? Journal of Public Economics, 88(9), 2009-2042.

Aristei, D., \& Bracalente, B. (2011). Measuring multidimensional inequality and Well-Being: Methods and an empirical application to Italian. Statistica, 71(2), 239-266.

Baker, L. A., Cahalin, L. P., Gerst, K., \& Burr, J. A. (2005). Productive activities and subjective wellbeing among older adults: The influence of number of activities and time commitment. Social Indicators Research,73(3), 431458.

Bartolini, S., \& Sarracino, F. (2014). Happy for how long? How social capital and economic growth relate to happiness over time. Ecological Economics, 108, 242-256.

Bartolini, S., Bilancini, E., Pugno, M., Destefanis, S., De Vito, M., Drago, F., \& Tiezzi, S. (2009). American decline in social capital and happiness: Is there a linkage? Mimeo. In University of Siena.

Bjornskov, C. (2003). The happy few: Cross country evidence on social capital and life satisfaction. Kyklos, 56, 3-16.

Bjørnskov, C. (2008). Social capital and happiness in the United States. Applied Research in Quality of Life, 3(1), 43-62.

Blanchflower, D. G., \& Oswald, A. J. (2008). Is well-being U-shaped over the life cycle? Social Science and Medicine, 66(8), 1733-1749.

Brown, S., \& Gray, D. (2016). Household finances and well-being in Australia: An empirical analysis of comparison effects. Journal of Economic Psychology, 53, 17-36.

Browning, C. R., \& Cagney, K. A. (2002). Collective efficacy and health: Neighborhood social capital and self rated physical functioning in an urban setting. Journal of Health and Social Behaviors, 43(4), 383-399.

Chang, W. (2009). Social capital and subjective happiness in Taiwan. International Journal of Social Economics, 36, 844-68.

Coleman, J. (1988). Social capital in the creation of human capital. American Journal of Sociology, 94, 95-120. 
Cook, K. E. (2001). Trust in society. Russell Sage Foundation.

Decancq, K., \& Lugo, M. A. (2013). Weights in multidimensional indices of wellbeing: An overview. Econometric Reviews, 32(1), 7-34.

Deci, E. L., \& Ryan, R. M. (2008). Hedonia, eudaimonia, and well being: An introduction. Journal of Happiness Studies, 9(1), 1-11.

Deeming, C. (2013). Addressing the social determinants of subjective wellbeing: The latest challenge for social policy. Journal of Social Policy, 42(3), 541565 .

Di Tella, R., Macculloch, R. J., \& Oswald, A. J. (2003). The macroeconomics of happiness. The Review of Economics and Statistics, 85(4), 809-827.

Diener, E. (2000). Subjective wellbeing: The science of happiness and a proposal for a national index. American Psychological Association, 55(1), 34-43.

Diener, E., Oishi, S., \& Lucas, R. E. (2003). Personality, culture, and subjective well being: Emotional and cognitive evaluations of life. Annual Review of Psychology, 54(1), 403-425.

Dolan, P., \& Metcalfe, R. (2012). Measuring subjective wellbeing: Recommendations on measures for use by national governments. Journal of Social Policy, 41(2), 409-427.

Dorn, D., Fischer, J. A., Kirchgässner, G., \& Sousa-Poza, A. (2007). Is it culture or democracy? The impact of democracy and culture on happiness. Social Indicators Research, 82(3), 505-526.

Elgar, F. J., Davis, C. G., Wohl, M. J., Trites, S. J., Zelenski, J. M., \& Martin, M. S. (2011). Social capital, health and life satisfaction in 50 countries. Health and Place, 17(5), 1044-1053.

Ferlander, S. (2007). The importance of different forms of social capital for health. Acta Sociologica, 50(2), 115-128.

Fowler, J. H., \& Christakis, N. A. (2008). Dynamic spread of happiness in a large social network: Longitudinal analysis over 20 years in the framingham heart study. British Medical Journal,337, 1-9, Available at: https://doi.org/10.1136/bmj.a2338

Fleche, S., Smith, C., \&Sorsa, P. (2011). Exploring determinants of subjective wellbeing in OECD countries: Evidence from world values survey. 
Organisation for Economic Co-operation and Development, Working Paper, Available at: http://dx.doi.org/10.1787/5kg0k6zlcm5k-en

Frey, B. S., \& Stutzer, A. (2000). Happiness, economy and institutions. The Economic Journal, 110(466), 918-938.

Glaeser, E. L., Laibson, D., Scheinkman, J. A., \& Soutter, C. L. (1999). What is social capital? The determinants of trust and trustworthiness. National Bureau of Economic Research, Working Paper, 7216.

Graham, C. (2011). Does more money make you happier? Why so much debate? Applied Research in Quality of Life, 6(3), 219.

Greenfield, E. A., \& Marks, N. F. (2004). Formal volunteering as a protective factor for older adults' psychological well-being. The Journals of Gerontology: Psychological Sciences and Social Sciences, 59(5), 258-264.

Gwozdz, W., \& Sousa-Poza, A. (2010). Ageing, health and life satisfaction of the oldest old: An analysis for Germany. Social Indicators Research, 97(3), 397-417.

Hasan, H. (2016). Does happiness adapt to increase in income? Evidence from Pakistan Socio economic survey (1998-2001). The Pakistan Development Review, 55(2), 113-122.

Hasan, H., \& Khan, H. (2015). Do Sen's capabilities determine happiness? Evidence from a unique survey data. International Journal of Happiness and Development, 2(2), 160-181.

Hawe, P., \& Shiell, A. (2000). Social capital and health promotion: A review. Social Science and Medicine, 51(6), 871-885.

Helliwell, J. F. (2003). How's life? Combining individual and national variables to explain subjective well being. Economic Modelling, 20(2), 331-360.

Helliwell, J. F. (2006). Well being, social capital and public policy: What's new? The Economic Journal, 116(510).

Helliwell, J. F., \& Putnam, R. D. (2004). The social context of well being. Philosophical Transactions of the Royal Society B: Biological Sciences, 359(1449), 1435-1446.

Helliwell, J. F., \& Wang, S. (2011). Trust and well-being. International Journal of Well-being, 1(1), 42-78. 
Hoffmann, R., Kröger, H., Tarkiainen, L., \& Martikainen, P. (2019). Dimensions of social stratification and their relation to mortality: A comparison across gender and life course periods in Finland. Social Indicators Research, 145(1), 349-365.

Jabeen, F., \& Khan, F. A. (2016). An empirical analysis of individual's happiness in Pakistan. Humanities and Social Sciences, 23(2), 181-199.

Kawachi, I., Kennedy, B. P., \& Glass, R. (1999). Social capital and self-rated health: a contextual analysis. American Journal of Public Health, 89(8), 1187-1193.

Kawachi, I., Kennedy, B. P., Lochner, K., \& Prothrow-Stith, D. (1997). Social capital, income inequality, and mortality. American Journal of Public Health, 87(9), 1491-1498.

Kawachi, I., Kim, D., Coutts, A., \& Subramanian, S. V. (2004). Commentary: reconciling the three accounts of social capital. International Journal of Epidemiology, 33(4), 682-690.

Knack, S., \& Keefer, P. (1997). Does social capital have an economic payoff? A cross-country investigation. The Quarterly Journal of Economics, 112(4), 1251-1288.

Layard, R. (2006). Happiness and public policy: A challenge to the profession. The Economic Journal, 116(510), 24-33.

Lenzen, M., \& Cummins, R. (2013). Happiness versus the environment: A case study of Australian lifestyles. Challenges, 4(1), 56-74.

Lin, N., Cook, K. S., \& Burt, R. S. (2001). Social capital: Theory and research. Transaction Publishers.

Lomas, J. (1998). Social capital and health: Implications for public health and epidemiology. Social Science and Medicine, 47(9), 1181-1188.

Maass, R., Kloeckner, C. A., Lindstrøm, B., \& Lillefjell, M. (2016). The impact of neighborhood social capital on life satisfaction and self-rated health: A possible pathway for health promotion? Health and Place, 42, 120-128.

Mackerron, G., \& Mourato, S. (2013). Happiness is greater in natural environments. Global Environmental Change, 23(5), 992-1000.

Ngamaba, K. H. (2017). Determinants of subjective wellbeing in representative samples of nations. European Journal of Public Health, 27(2), 377-382. 
Ngoo, Y. T., Tey, N. P., \& Tan, E. C. (2015). Determinants of life satisfaction in Asia. Social Indicators Research, 124(1), 141-156.

Poortinga, W. (2006). Social capital: An individual or collective resource for health? Social Science and Medicine, 62(2), 292-302.

Putnam, R. (1993). The prosperous community: Social capital and public life. The American Prospect, 13(4).

Putnam, R. (2001). Social capital: Measurement and consequences. Canadian Journal of Policy Research, 2(1), 41-51.

Putnam, R. D. (2000). Bowling alone: America's declining social capital. Culture and Politics, 6(1), 223-234. Available at: https://doi.org/10.1007/978-1349-62965-7_12

Ram, R. (2010). Social capital and happiness: Additional cross country evidence. Journal of Happiness Studies, 11(4), 409-418.

Rodríguez-Pose, A., \& Von Berlepsch, V. (2014). Social capital and individual happiness in Europe. Journal of Happiness Studies, 15(2), 357-386.

Seligman, M. E., \& Royzman, E. (2003). Happiness: The three traditional theories. Authentic Happiness Newsletter, (July).

Sabatini, F. (2007). The empirics of social capital and economic development: A critical perspective. Working Paper, 15.2006, Available at: https://dx.doi.org/10.2139/ssrn.879712

Sarracino, F. (2013). Determinants of SWB in high and low income countries: Do happiness equations differ across countries. The Journal of SocioEconomics, 42(3), 51-66.

Shams, K. (2014). Determinants of SWB and poverty in rural Pakistan: A micro level study. Social Indicators Research, 119(3), 1755-1773.

Steptoe, A., Deaton, A., \& Stone, A. A. (2015). Subjective wellbeing, health, and ageing. The Lancet, 385(9968), 640-648.

Sachs, J. D., Layard, R., \& Helliwell, J. F. (2018). World Happiness Report 2018. New York, Sustainable Development Solutions Network, 12761.

Tsuruta, K., Shiomitsu, T., Hombu, A., \& Fujii, Y. (2019). Relationship between social capital and happiness in a Japanese community: A cross sectional study. Nursing and Health Sciences, 21(2), 245-252. 
Vaughan, D. A., Kashner, J. B., Stock, W. A., \& Richards, M. (1985). A structural model of subjective well being: A comparison of ethnicity. Social Indicators Research, 16(3), 315-332.

Veenstra, G. (2000). Social capital, SES and health: An individual level analysis. Social Science and Medicine, 50(5), 619-629.

Vega, J. (2016). Happiness and quality of life in Mexico: Conceptual and geographical considerations. Handbook of Happiness Research in Latin America, Springer, Dordrecht, 463-475.

Vemuri, A. W., \& Costanza, R. (2006). The role of human, social, built, and natural capital in explaining life satisfaction at the country level: Toward a national well being index (NWI). Ecological Economics, 58(1), 119-133.

Wen, M., Browning, C. R., \& Cagney, K. A. (2003). Poverty, affluence, and income inequality: Neighborhood economic structure and its implications for health. Social Science and Medicine, 57(5), 843-860.

Wunder, C., Wiencierz, A., Schwarze, J., \& Küchenhoff, H. (2013). Well being over the life span: Semiparametric evidence from British and German longitudinal data. Review of Economics and Statistics, 95(1), 154-167.

Yip, W., Subramanian, S. V., Mitchell, A. D., Lee, D. T., Wang, J., \& Kawachi, I. (2007). Does social capital enhance health and well-being? Evidence from rural China. Social Science and Medicine, 64(1), 35-49. 
Social Capital as a Resource of Subjective Well-Being:

Mediating Role of Health Status

\section{Appendix}

\section{Appendix A: Variables Description}

\begin{tabular}{ll}
\hline Variables & \multicolumn{1}{c}{ Definition } \\
\hline Age & 1, if $<=25 ; 2$, if $26-35 ; 3$, if $36-45 ; 4$, if $46-55 ; 5$, if $>55$ \\
Income & I1 if EIIR $<=15000 ;$ I2, if 15001-30000; I3, if 30001-45000; I4, if 45001-60000; I5, if $>60000$ \\
Children & No Child=1; One Child=2; TwoChildren=3; Three Children=4; More than 4 Children=5 \\
& $\begin{array}{l}\text { T1= Family Trust; T2= Neighbour's Trust; T3=Friends Trust; T4=Trust on People to whom } \\
\text { meet first Time }\end{array}$ \\
NoF & Number of Close Friends \\
Mem. & Dummy of Memberships; "1", if 1 or more Memberships otherwise "0" \\
\hline
\end{tabular}

Appendix B: Structural Equation Model of Control Variables for the Association Between Social Capital and SWB: Mediating Role of Self-Reported Health Status (Very Good to Very Poor)

\begin{tabular}{|c|c|c|c|}
\hline VARIABLES & Happiness & Life Satisfaction & Worth-While \\
\hline & Odd Ratios & Odd Ratios & Odd Ratios \\
\hline \multirow[t]{2}{*}{ Gender: Female } & 1.11 & 0.93 & 1.05 \\
\hline & $(0.13)$ & $(0.11)$ & $(0.12)$ \\
\hline \multicolumn{4}{|l|}{ Education } \\
\hline \multirow[t]{2}{*}{ Primary or Below } & 1.04 & 1.40 & 1.17 \\
\hline & $(0.30)$ & $(0.41)$ & $(0.35)$ \\
\hline \multirow[t]{2}{*}{ Secondary } & 1.23 & $2.11 * * *$ & 1.20 \\
\hline & $(0.34)$ & $(0.59)$ & $(0.34)$ \\
\hline \multirow[t]{2}{*}{ Matric (10 Years) } & $2.16^{* * *}$ & $2.31 * * *$ & $2.11 * * *$ \\
\hline & $(0.54)$ & $(0.59)$ & $(0.53)$ \\
\hline \multirow[t]{2}{*}{ Intermediate (12 Years) } & $3.66^{* * *}$ & $4.10 * * *$ & $2.61 * * *$ \\
\hline & $(0.94)$ & (1.08) & $(0.68)$ \\
\hline \multirow[t]{2}{*}{ Bachelor (14 Years) } & $4.28 * * *$ & $4.20 * * *$ & $2.74 * * *$ \\
\hline & (1.03) & (1.04) & $(0.67)$ \\
\hline \multirow[t]{2}{*}{ Masters (16 Years) } & $5.65 * * *$ & $4.70 * * *$ & $3.53 * * *$ \\
\hline & $(1.37)$ & $(1.17)$ & $(0.87)$ \\
\hline \multirow[t]{2}{*}{ MPhil or above (18 Years or more) } & $6.16^{* * *}$ & $4.56^{* * *}$ & $3.68 * * *$ \\
\hline & (1.63) & $(1.24)$ & (1.00) \\
\hline \multirow[t]{2}{*}{ Certification/ Engineer/Medical } & $6.96^{* * *}$ & $8.06^{* * *}$ & $7.18 * * *$ \\
\hline & (2.59) & $(3.05)$ & $(2.70)$ \\
\hline \multicolumn{4}{|l|}{ Employment Status } \\
\hline Part Time & $0.55^{* * * *}$ & $0.69 * *$ & $0.74 *$ \\
\hline
\end{tabular}




\begin{tabular}{cccc} 
& $(0.09)$ & $(0.12)$ & $(0.13)$ \\
Self-Employed & $1.55^{* * *}$ & $1.31^{* *}$ & $1.37^{* *}$ \\
\multirow{3}{*}{ Retired } & $(0.19)$ & $(0.16)$ & $(0.17)$ \\
& 1.21 & $1.54^{*}$ & 1.01 \\
Unemployed & $(0.29)$ & $(0.37)$ & $(0.24)$ \\
& 1.02 & 1.11 & 0.93 \\
& $(0.15)$ & $(0.17)$ & $(0.14)$
\end{tabular}

Marital Status

\begin{tabular}{cccc} 
Married & $1.27^{* *}$ & $1.29^{* *}$ & $1.28^{* *}$ \\
& $(0.14)$ & $(0.14)$ & $(0.14)$ \\
Widowed & 0.75 & 0.82 & 1.13 \\
& $(0.23)$ & $(0.24)$ & $(0.34)$ \\
Divorced & 0.53 & $0.35^{* *}$ & 0.63 \\
& $(0.29)$ & $(0.18)$ & $(0.36)$ \\
\hline Log Likelihood & -8313.89 & -8213.47 & 8413.11 \\
Observations & 1566 & 1566 & 1566
\end{tabular}

“***", “**" and "**" denotes the significance level at 1\%, 5\% and 10\% respectively, while Standard Errors are shown in parenthesis.

Appendix C: Structural Equation Model of Control Variables for the Association Between Social Capital and SWB: Mediating Role of Self-Reported Health Status (Very Good to Very Poor)

\begin{tabular}{cccc}
\hline Variables & Happiness & Life Satisfaction & Worth-While \\
\hline Odd Ratios & Odd Ratios & Odd Ratios \\
\hline Residence: Rented & 0.91 & $0.81^{*}$ & 1.01 \\
& $(0.11)$ & $(0.10)$ & $(0.12)$ \\
Agri-land: Yes & $1.54^{* * *}$ & $1.62^{* * *}$ & $1.29^{* *}$ \\
& $(0.16)$ & $(0.17)$ & $(0.14)$ \\
Loan: Yes & $0.59^{* * *}$ & $0.60^{* * *}$ & $0.74^{* * *}$ \\
& $(0.07)$ & $(0.07)$ & $(0.09)$ \\
\hline Log Likelihood & -8389.38 & -8248.05 & -8453.1 \\
Observations & 1566 & 1566 & 1566
\end{tabular}

“***", "***" and "**” denotes the significance level at 1\%,5\% and 10\% respectively, while Standard Errors are shown in parenthesis. 
Social Capital as a Resource of Subjective Well-Being:

Mediating Role of Health Status

Appendix D: Structural Equation Model of Control Variables for the Association Between Social Capital and SWB: Mediating Role of Self-Reported Health Status (Very Good to Very Poor)

\begin{tabular}{|c|c|c|c|c|}
\hline & Variables & Happiness & Life Satisfaction & Worth-While \\
\hline & & Odd Ratios & Odd Ratios & Odd Ratios \\
\hline \multicolumn{5}{|l|}{ SOGH } \\
\hline \multirow{2}{*}{\multicolumn{2}{|c|}{ Somewhat }} & 0.82 & 1.08 & 0.73 \\
\hline & & $(0.18)$ & $(0.23)$ & $(0.16)$ \\
\hline \multirow{2}{*}{\multicolumn{2}{|c|}{ Neutral }} & 0.76 & 1.09 & 0.79 \\
\hline & & $(0.17)$ & $(0.23)$ & $(0.17)$ \\
\hline \multirow{2}{*}{\multicolumn{2}{|c|}{ Not Much }} & 0.72 & 0.88 & $0.65 * *$ \\
\hline & & $(0.16)$ & $(0.19)$ & $(0.14)$ \\
\hline \multirow{2}{*}{\multicolumn{2}{|c|}{ Not at all }} & $0.50 * * *$ & 0.87 & $0.44 * * *$ \\
\hline & & $(0.12)$ & $(0.21)$ & $(0.11)$ \\
\hline
\end{tabular}

$\mathrm{SOPH}$

\begin{tabular}{|c|c|c|c|}
\hline \multirow[t]{2}{*}{ Somewhat } & $0.77 * *$ & $0.58 * * *$ & $0.68 * * *$ \\
\hline & $(0.10)$ & $(0.08)$ & (0.09) \\
\hline \multirow[t]{2}{*}{ Neutral } & $0.54 * * *$ & $0.43 * * *$ & $0.51 * * *$ \\
\hline & $(0.08)$ & $(0.06)$ & $(0.08)$ \\
\hline \multirow[t]{2}{*}{ Not Much } & $0.58 * * *$ & $0.60 * *$ & 0.75 \\
\hline & $(0.12)$ & $(0.12)$ & $(0.15)$ \\
\hline \multirow[t]{2}{*}{ Not at all } & $0.44^{* * *}$ & $0.36^{* * *}$ & $0.57 * *$ \\
\hline & $(0.11)$ & $(0.09)$ & $(0.14)$ \\
\hline \multirow[t]{2}{*}{ SWH } & $1.12^{* *}$ & $1.13 * * *$ & $1.12 * *$ \\
\hline & $(0.05)$ & $(0.05)$ & $(0.05)$ \\
\hline \multirow[t]{2}{*}{ DHS } & 0.97 & 0.97 & 1.07 \\
\hline & $(0.05)$ & $(0.05)$ & $(0.05)$ \\
\hline \multirow[t]{2}{*}{ FDHS } & $1.42 * * *$ & $1.52 * * *$ & $1.29 * * *$ \\
\hline & $(0.10)$ & $(0.11)$ & $(0.09)$ \\
\hline \multirow[t]{2}{*}{ Institutional Quality } & $1.11^{* *}$ & $1.10^{* *}$ & $1.10 * *$ \\
\hline & $(0.05)$ & $(0.05)$ & $(0.05)$ \\
\hline \multirow[t]{2}{*}{ Government Effectiveness } & $1.11^{* *}$ & $1.09 *$ & 1.04 \\
\hline & $(0.05)$ & $(0.05)$ & $(0.05)$ \\
\hline \multirow[t]{2}{*}{ Corruption: No } & $1.49 * * *$ & $1.53 * * *$ & $1.37 * *$ \\
\hline & $(0.19)$ & $(0.20)$ & $(0.18)$ \\
\hline Log Likelihood & -8286.2 & -8139.40 & -8349.75 \\
\hline Observations & 1545 & 1545 & 1545 \\
\hline
\end{tabular}

“***", “**" and "**” denotes the significance level at 1\%,5\% and 10\% respectively, while Standard Errors are shown in parenthesis. 
Appendix E: Structural Equation Model of Control Variables for the Association Between Social Capital and SWB: Mediating Role of Self-Reported Health Status (Very Good to Very Poor)

\begin{tabular}{|c|c|c|c|}
\hline Variables & Happiness & Life Satisfaction & Worth-While \\
\hline & Odd Ratios & Odd Ratios & Odd Ratios \\
\hline \multicolumn{4}{|l|}{ Political Interest } \\
\hline \multirow[t]{2}{*}{ Somewhat } & 1.08 & 1.05 & 0.93 \\
\hline & $(0.14)$ & $(0.13)$ & $(0.12)$ \\
\hline \multirow[t]{2}{*}{ Not Much } & 1.14 & 0.94 & $0.76 * *$ \\
\hline & $(0.16)$ & $(0.13)$ & $(0.11)$ \\
\hline \multirow[t]{2}{*}{ Not at all } & $0.66^{* * * *}$ & $0.71 * *$ & $0.53^{* * * *}$ \\
\hline & $(0.09)$ & $(0.10)$ & $(0.07)$ \\
\hline \multirow[t]{2}{*}{ Crime: Yes } & 1.01 & $0.75 * *$ & \\
\hline & $(0.14)$ & $(0.10)$ & \\
\hline \multirow[t]{2}{*}{ Freedom } & $1.49 * * *$ & $1.61 * * *$ & $1.53 * * *$ \\
\hline & $(0.03)$ & $(0.04)$ & $(0.03)$ \\
\hline \multirow[t]{2}{*}{ Security Adaptation } & $0.87 * * *$ & $0.87 * * *$ & $0.86^{* * * *}$ \\
\hline & $(0.04)$ & $(0.04)$ & $(0.04)$ \\
\hline \multirow[t]{2}{*}{ Worrisome on Terrorism } & 0.94 & $0.91 * *$ & 1.03 \\
\hline & $(0.04)$ & $(0.04)$ & $(0.04)$ \\
\hline Log Likelihood & -8223.22 & -8024.61 & -8239.13 \\
\hline Observations & 1566 & 1566 & 1566 \\
\hline
\end{tabular}

